\title{
Cracking in sweet cherries: A comprehensive review from a physiological, molecular, and genomic perspective
}

\author{
Cristián Balbontín ${ }^{1 *}$, Héctor Ayala ${ }^{1}$, Richard M. Bastías ${ }^{1}$, Gerardo Tapia ${ }^{2}$, Miguel Ellena ${ }^{3}$, \\ Carolina Torres ${ }^{4}$, José Antonio Yuri ${ }^{4}$, José Quero-García ${ }^{5}$, Juan Carlos Ríos ${ }^{6}$, and Herman Silva ${ }^{6}$
}

\begin{abstract}
Rain-induced cracking in fruits of sweet cherry (Prunus avium [L.]) is a problem in most producing areas of the world and causes significant economic losses. Different orchard management practices have been employed to reduce the severity of this problem, although a complete solution is not yet available. Fruit cracking is a complex phenomenon and there are many factors that seem to be involved in its development. During the last decade, genomic and biochemical approaches have provided new insights on the different mechanisms that could be involved in the differential susceptibility shown by commercial cultivars. For instance, sweet cherry genome and transcriptome sequencing information have provided new opportunities to study the expression and structure of genes involved in cracking, which may help in the development of new tolerant cultivars. The present review summarizes, discuss, and integrate most of the recently generated information in cultural practices, physiology, biochemistry, and genetics in relation to cracking in sweet cherries.
\end{abstract}

Key words: Physiology, functional genomics, RNA seq.

\section{INTRODUCTION}

Cracking and splitting of fruit caused by rainfall before harvest, is a serious economic problem in some fruit species including cherries and grapes (Simon, 2006). In sweet cherry (Prunus avium [L.]), rain-induced cracking before harvest is the most important crop loss in many cherry-producing areas. Chile is the main cherry exporter in the Southern Hemisphere; therefore, cracking can seriously compromise quality and crop profitability (Valenzuela, 2007). This disorder is characterized by cracks developed after a rain on the skin of the fruits, sometimes deep into the flesh, affecting the stem end area, the calyx end and the cheeks of the fruit (side cracks). These cracked cherries lose their commercial value for fresh-fruit market, and can be only sold locally or to processing industry.

${ }^{1}$ Universidad de Concepción, Facultad de Agronomía, Av. Vicente Méndez 595, Chillán, Chile.

*Corresponding author (cbalbontin@udec.cl).

${ }^{2}$ Instituto de Investigaciones Agropecuarias INIA, Av. Vicente Méndez 515, Chillán, Chile.

${ }^{3}$ Instituto de Investigaciones Agropecuarias INIA, Camino CajónVilcún km 10, Temuco, Chile.

${ }^{4}$ Universidad de Talca, Facultad de Ciencias Agrarias, Av. Lircay s/n, Talca, Chile.

${ }_{5}^{5}$ INRA-Bordeaux, Genetics and Breeding Department, 71 Avenue Edouard Bourlaux BP81, Villenave d'Ornon, France.

${ }^{6}$ Universidad de Chile, Facultad de Ciencias Agronómicas, Av. Santa Rosa 11315, 8820808 La Pintana, Santiago, Chile.

Received: 21 November 2012

Accepted: 26 January 2013.
Rain-induced cracking in cherries is a complex phenomenon and there are several factors associated with its occurrence. Cultivar, growing conditions, irrigation management, rootstock, fruit size, flesh osmotic potential, cuticular characteristics of the skin and stage of fruit development, are among the most commonly reported factors influencing the onset of the problem (Verner and Blodgett, 1931; Sawada, 1931; Kertesz and Nebel, 1935; Considine and Kriedemann, 1972; Christensen, 1976; Yamamoto et al., 1990; Roser, 1996; Christensen, 1996; Sekse, 1998; Christensen, 2000; Lane et al., 2000; Moing et al., 2004). The basic mechanism causing this disorder, although not fully understood, seems to be the rapid increase in water absorption by the fruit. This increment on the water content of the fruit may be the result of the direct water absorption through the fruit skin cuticle or its absorption through the vascular system (Kertesz and Nebel, 1935; Christensen, 1973; Sekse, 1995; Measham et al., 2009). Also, three types of cracking have been described in the literature: stem, apical, and side cracks (Christensen, 1972). Research from Australia suggests that the type of cracking (i.e., stem, apical, and side) may not be an expression of the severity of a single process, but may rather be the manifestation of the different water uptake pathways during the onset of the problem (Measham et al., 2009; 2010).

\section{Cultural practices used for managing fruit cracking}

Management practices that are used to reduce fruit cracking can be classified into three groups: (1) reduction of fruit wetting in the final stage of ripening; (2) reduction 
of fruit osmotic potential during the occurrence of rain in fruit; and, (3) protection of the fruit with elastics and/ or hydrophobic films. Prevent cracking by either avoid physically contact of rainwater with the fruit cuticle or, by chemically modifying osmotic potential of the outside solution (i.e., rain water deposited on the fruit) has been normally used.

Blowing off the water deposited on the fruit by flying helicopters or spraying equipment, is commonly used by growers worldwide. The use of hydrophobic films has also been reported to physically prevent water uptake through the cuticle. Torres et al. (2009a) reported significant reduction of induced cracking when fruit was sprayed with a lipophilic hydrophobic compound which formed a film over the fruit. Schrader and Sun (2005) have also reported significant reduction of cherry cracking when hydrophobic films were used under commercial conditions. Several researchers have reasoned that application of a salt or sugar to cherries could help to balance osmotic potentials and slow uptake of rainwater through the cuticle during a rain (Lang and Hayden, 1997; Lang et al., 1997; Fernandez and Flore, 1998; Lang and Flore, 1999; Heacox, 2001). Additionally, several authors have also reported a reduction in cracking after preharvest Ca sprays to the fruit (Glenn and Poovaiah, 1989; Yamamoto et al., 1992; Sekse, 1995), but results have been inconsistent, and with side effects, like a reduction in the size of fruits (Facteau et al., 1987; Podestá et al., 2001).

Torres et al. (2009b) showed that the cracking index was reduced when fruit was immersed in $\mathrm{Ca}$ solutions $(1 \% \mathrm{v} / \mathrm{v})$ compared to distilled water. This was assessed in the laboratory by submerging fruit in different osmotic solutions for $8 \mathrm{~h}$. After this time, the number of cracked fruit was counted and the cracking index calculated (Christensen, 1972). As fruit ripened, cracking index increased progressively. According to laboratory tests and field trials, hydrophobic films alone or mixed with calcium chloride $\left(\mathrm{CaCl}_{2}\right)$ solutions can also reduce cherry cracking (Palma, 2009; Torres et al., 2009b).

The use of physical and mechanical barriers to prevent rainwater to touch the fruit, such as polyethylene covers, significantly reduce fruit cracking; however, this system does not guarantee total control of the problem (Lugli et al., 2001) and its high implementation costs limit massive use of this technology (Bergamini and Tomasi, 1994; Lugli et al., 2001). Polyethylene and other type of covers are installed as fix or mobile structures. The fix type, once installed, is not removed until the end of harvest, while the mobile covers set over the trees only in case of rain. The mobile systems have a minimal effect on the orchard microclimate (temperature, relative humidity, and light), while fix covers may cause an increase in temperature and relative humidity, particularly at the top of the tree, deteriorating fruit quality (Lugli et al., 2001). More recently silicon-based products have been used to form layers over the fruit (Ellena et al., 2006; Sorrenti et al., 2008). Treatment with $0.7 \%$ sodium silicate applied weekly (three times) from the color turning stage until 1 wk before harvest reduces the percentage of fruit cracking. The effectiveness of foliar Si to prevent cracking in sweet cherries may be due to both the increase of the elasticity of the cell wall and reinforcing structures, forming a protective layer that minimize the penetration of water and fungal pathogens (Ma, 2007). However, results with silicon have been erratic at the orchard level. This means that physical barriers may be effective in reducing cracking under certain conditions, like areas with low rainfall during fruit ripening.

\section{Physiological factors involved in fruit cracking}

Physiological mechanisms that have been studied to explain fruit cracking include water uptake by the fruit, fruit osmotic potential, anatomical aspects of fruit cells (number and size), cuticle physical properties, and dynamics of fruit growth.

The first factor proposed to explain fruit cracking was the excess water absorbed by roots or directly by the fruit surface. Water absorbed through the roots during fruit ripening may play an important role in the development of cracking, because it induces an increase in the internal turgor pressure of the fruit (Kertesz and Nebel, 1935; Considine and Kriedemann, 1972; Yamamoto et al., 1990, Measham et al., 2010). Nevertheless, other researchers have proposed that water absorption through fruit skin is the most important factor in the development of this phenomenon (Sawada, 1931; Verner and Blodgett, 1931; Christensen, 1976). The water uptake threshold at which fruit cracks was closely related to cracking susceptibility among some cultivars (Lane et al., 2000).

Fruit osmotic potential is an additional factor that has been correlated with the development of cracking. Some researchers have found a positive correlation between fruit osmotic potential and occurrence of fruit cracking under controlled conditions (immersion of fruit in distilled water). These studies show that the osmotic potential of cherries not only varies along the growing season, but also among different cultivars (Christensen, 1996; Sekse, 1998). They also suggest that osmotic potential could be a useful parameter to determine fruit susceptibility to raininduced cracking during its development and the right time to apply external treatments to mitigate this problem (Torres et al., 2009b). Recent information, however, suggest that fruit osmolarity is not a good physiological indicator of the degree of susceptibility. Moing et al. (2004) showed that, at commercial maturity, when fruit susceptibility to cracking is highest, no clear differences appeared between susceptible and tolerant varieties in flesh or skin osmolarity, suggesting that cuticle properties and no fruit osmolarity may play an important role in the development of this problem.

Very early studies suggest that firmness and size of fruit 
could be correlated with the development of cracking. It was initially postulated that fruit volume increase, due to water uptake, affects more severely larger and firmer cultivars (Tucker, 1934). However, others studies comparing larger number of cultivars (Zielinski, 1964; Christensen, 1975) found no significant relationship between these parameters and the development of fruit cracking.

Cultivar susceptibility varies with the stage of fruit development (Christensen, 1973). Sweet cherry presents a double-sigmoid pattern of fruit growth (Coombe, 1976), which divide the fruit development period (FDP) into three distinctive growth phases: Phase I, which goes from full bloom to about 20-25 d after full bloom (DAFB), is characterized by the rapid division of mesocarp cells; Phase II, characterized by embryo development and endocarp hardening; and, Phase III, characterized by cell enlargement resulting in the final fruit size. Phase III is a critical moment for cracking and in earlier studies was closely linked to the rapid expansion of fruit mesocarp (Christensen, 1973). As cell enlargement progress in the mesocarp, the elastic capacity of the cuticle is exceeded as a consequence of the high fruit internal pressure during Phase III, which increases the incidence of cuticular fractures resulting higher water flux into the fruit (Knoche et al., 2001). Some studies concluded that cuticular fractures in sweet cherry fruits contribute $60 \%$ of water diffusion during Phase III (Gibert et al., 2005). Recent studies demonstrate a clear difference in fruit growth rate and water uptake rate patterns among sweet cherry cultivars with contrasting levels of cracking susceptibility (Bastías et al., 2010). For example, in this study it was shown that the higher absolute fruit growth rate was reached at 50-58 DAFB in the susceptible cv. Bing, while in cultivars with more tolerance, such as 'Kordia', the maximum growth rate was reached later in the growing season (72 DAFB). Accordingly, both differences in dynamics of fruit growth and properties of the cuticle to support the extending of the fruit would be useful to fully understand the development of this problem. Moreover, recent studies have suggested that primary causes of fruit cracking could be related with the increase in fruit surface area during fruit development in the absence of deposition of cuticle membrane (Alkio et al., 2012).

\section{Biochemical factors involved in cherry fruit cracking}

Some of the major problems associated with an excessive entrance of water into fruit cells are disruption of the cell wall, leaching of vacuolar contents and loss of cell structure, including dermal layers (Peschel et al., 2007). Cuticular membrane or cuticle is a hydrophobic semipermeable membrane, composed of multiple layers of lipids that cover aerial surfaces of plants. Its main function is to provide a barrier against pathogens and to diminish water loss (Buda et al., 2009). The cuticle has two mayor types of lipids: cutin and cuticular waxes (Kunst and Samuels, 2009). In cherries, waxes of the cuticle play an important role in water permeability. If the cuticle is removed, water intake increases significantly (Knoche et al., 2000). Qualitative and quantitative analysis of waxes from fruits from different cherry cultivars show that its components are mainly triterpenes (76\%), alkanes (19\%) and alcohols (1\%) (Peschel et al., 2007). Triterpenes are formed by six isoprene units (Croteau et al., 2000). Alcohols (primary and secondary) are organic compounds in which the hydroxy functional group is esterified to fatty acids (Samuels et al., 2008). Alkanes are linear chain saturated hydrocarbons, branched or cyclic, that does not have functional groups, making their reactivity very reduced. They do not form hydrogen bonds and are insoluble in polar solvents (Boese et al., 1999), conferring the semi permeability property to waxes. Studies in cherry tomato (Solanum lycopersicum L.) demonstrated that the silencing of lecer6 elongase, involved in the extension of long-chain fatty acids, generated three to eight times more dehydration per unit surface area of fruit than the untransformed plant. These fatty acids are key components for the synthesis of aliphatic compounds like alkanes that are part of the cuticular wax (Vogg et al., 2004). The alkane's quantification for these tomatoes, showed a considerable decrease of the concentration of n-alkanes from 28 to $30 \mathrm{C}$ (Leide et al., 2007).

The proportion and type of alkanes seem to be important for the resistance to cracking. Rios et al. (2011) and Silva et al. (2012) have found that alkanes with 28 to $30 \mathrm{C}$ are present at different concentrations in different sweet cherry cultivars. 'Lapins' is less susceptible to cracking and reached significantly lower concentrations of this hydrocarbon compared to other cultivars. This component is essential for water permeability in the epicuticular waxes of fruits and leaves, therefore a lower concentration of this component, would allow more efficient water movement. Therefore, difference in concentration of these alkanes could be an important factor to explain different behavior of various cultivars to cracking.

\section{Genetics and molecular factors involved in fruit cracking}

Cultivar differences in cracking susceptibility are considerable, but there is no one cultivar totally tolerant to the problem (Roser, 1996; Christensen, 2000). The development of high quality crack-resistant cultivars and the identification of genes involved in resistance is a major objective in most breeding programs. The selection of a tolerant cultivar could involve several years of field observations and in vitro cracking assays. Nevertheless, the association between field records and laboratory tests is not always perfect. In this regard, the use of technologies that enable a better understanding of the causes or genetic factors that influence the development of fruit cracking could be useful in the development of molecular tools that 
allow for early selection of individuals with tolerance to this problem.

A research team at Institut National de la Recherche Agronomique INRA-Bordeaux (France) has recently initiated a research program in order to search for the genetic determinism of fruit cracking tolerance. A classical quantitative trait locus (QTL) approach was implemented. A genetic map was developed based on 125 full-sib hybrids coming from a cross between 'Regina' and 'Lapins' (hereafter called $\mathrm{R} \times \mathrm{L}$ ). 'Regina' is one of the most cracking-tolerant commercial cultivar and 'Lapins' has an intermediate tolerance to cracking. The genetic map was first built with SSR (or microsatellite) markers (Dirlewanger et al., 2004) and it has recently been highly saturated with Single Nucleotide Polymorphism (SNP) markers (Klagges et al., 2013). These SNP markers were mapped from a chip of 6000 markers developed within RosBREED project (www.rosbreed.org). Preliminary results showed a low correlation between field and in vitro craking. Hence, a special system was developed to study cracking tolerance, consisting in an overhead sprinkling irrigation system to simulate rainfall spells. Each genotype from the $\mathrm{R} \times \mathrm{L}$ progeny, grafted on 'Tabel Edabriz' rootstock, was planted in a large pot and placed in tunnels equipped with the overhead sprinklers. Slightly before maturity and irrigated during several hours at fixed times and for $5 \mathrm{~d}$. Every day, the number of cracked fruits, out of a total of 100 fruits, was counted and removed (Quero-Garcia et al., 2009). This methodology was compared to cracking tolerance values observed in field conditions during three successive years (2008, 2009, and 2010). Within the field, for all $\mathrm{R} \times \mathrm{L}$ genotypes planted in the field, on their own roots, 100 fruits were harvested at physiological maturity and percentage of cracked fruits was evaluated.

Quantitative trait locus detection studies were conducted for both types of cracking tolerance, measured in tunnel or under field conditions (QueroGarcia et al., 2012). Since previous studies showed that cracking mechanisms differ depending on the fruit region that cracked (Christensen 1996; Measham et al., 2010), three different types of cracking were considered: pistillar end, stem end, and fruit side. Studies conducted at INRA-Bordeaux confirmed the complexity of cracking tolerance, since very few significant QTL were identified and most of them were not identified during all the years of the study. Interestingly, QTL for cracking tolerance at each fruit region were detected on different linkage groups, which confirmed that cracking in each area involves different genetic mechanisms. Overall, QTL detected for stem end and pistillar end cracking tolerance were more significant than QTL detected for fruit side cracking tolerance. This result could be explained by the fact that fruit side cracking may result from initial cracks at the pistillar end or at the stem end and, therefore, is a more complex type of cracking. Finally, the highest and most stable QTL, which could explain up to $15 \%$ of the phenotypic variability, was found for pistillar end cracking tolerance. Surprisingly, this QTL was identified every year by analyzing field data. Indeed, field data unexpectedly allowed the detection of stronger QTL than tunnel data.

Genome and transcriptomic sequences are useful tools for unveiling signal transduction pathways as well as novel genes (Velasco et al., 2010; Shulaev et al., 2011; Argout et al., 2011). The sequencing of sweet cherry genome is underway (Koepke et al., 2010). During the last $2 \mathrm{yr}$ the genome has been sequenced with an actual coverage of $82 x$. This project has allowed knowing different genes and signal transduction pathways and also identifying putative markers for this disorder. Silva et al. (2012) have found some genes involved in the synthesis of alkenes. They have been sequencing the transcriptome of few sweet cherry cultivars and performed northern digital and qPCR analysis to validate some genes that may be involved in cracking.

In depth studies about anatomy and molecular events that occur in fruit skin during fruit development are available for other species in which cracking is also a major problem. An important contribution to the understanding of multiple metabolic and genetic phenomena that occur in the fruit skin during ripening has been made in tomato (Mintz-Oron et al., 2008). This study describes the differential expression of genes at different fruit developmental stages and in different tissues of the fruit, to identify genes expressed specifically in the skin at ripening. Among the multiples genes found, there are wax biosynthesis transcriptional activators and genes involved in cell wall modification. Further evidence of the relationship between fruit cracking and properties and composition of the cuticle is provided by Vogg et al. (2004) in tomato, where the mutation of the CER6 gene ( $\beta$-ketoacyl-CoA synthase), leads to an alteration of the cuticular wax composition and increases water permeability. An interesting work about putative genes involved in the cuticle formation in sweet cherry was recently published by Alkio et al. (2012). In this research, the authors propose that constant strain suffered by the cuticle, could be a result of the cessation of cuticle membrane deposition during fruit growth. Transcript levels of several genes were analyzed during several stages of fruit development, finding that cessation of the cuticle deposition during early stages of this process, is consistent with lower levels of transcription of genes possibly involved in wax and cutin synthesis pathways.

The mechanisms of cell wall modification during ripening have also been linked to the development of fruit cracking. Ripening and fruit softening are the result of combined action of numerous enzymes such as polygalacturonase (PG), pectinesterase (PE), expansin and $\beta$-galactosidase (Brummell and Harpster, 2001). Antisense inhibition of PE and PG activity in tomato 
has been shown to alter both the levels of cracking and viscosity of the fruits, while suppression of the ripeningrelated expansin (Exp1) and tomato $\beta$-galactosidase 4 (TBG4) increases fruit firmness (Brummell et al., 1999; Smith et al., 2002). On the other hand, the relationship between activity of cell wall enzymes and cuticular layer has been demonstrated in tomato by Moctezuma et al. (2003) as a result of antisense suppression of a $\beta$-galactosidase gene (TBG6). The fruits obtained from these transgenic lines showed a substantial increase in the level of cracking.

In cherry fruit, preliminary studies suggest that transcript levels of $\beta$-galactosidase gene vary during fruit development process, showing their highest transcript levels in the fruit set stage, declining as ripening advances (Balbontín et al., 2012). These results agree with those reported by Kovács et al. (2008), who showed that the maximum $\beta$-galactosidase activity in cherry fruit occurs in the early stages of active growth and then decrease abruptly during ripening. Furthermore, when the transcript level of this gene is compared by real time PCR in two cultivars with contrasting degrees of tolerance, 'Kordia' (tolerant) and 'Bing' (susceptible), expression was higher in all stages analyzed in the more resistant cultivar. This may provide greater flexibility in the fruit cell wall to prevent emergence of microfractures that occur in more advanced fruit development stages (Knoche et al., 2001).

The expansins are non enzymatic proteins involved in cell wall extension, in a $\mathrm{pH}$ dependent manner, can be considered as regulators of the elongation of plant cells. According to the proposed model, expansins act by breaking down links between cellulose microfibrils and xyloglucans molecules allowing relaxation and expansion of cell wall under tensile stress of fruit softening (McQueenMason et al., 1992; McQueen-Mason and Cosgrove, 1995; Cosgrove, 2000). Although knowledge about the role of expansin proteins in cherry fruit cracking is still limited, in other species such as apple and litchi, levels of transcription of genes coding for expansin have been correlated with fruit cracking. In apples, six expansin genes were identified and their expression patterns were studied during fruit growth. Among them, MdEXPA3 is mainly expressed during the fruit enlargement phase (Wakasa et al., 2003) and its expression in pericarp tissues has been associated with reduced level fruit cracking (Kasai et al., 2008). In addition, an expansin gene has been identified in litchi and their levels of transcription in pericarp tissues have shown differences between litchi cultivars with contrasting grade of cracking susceptibility (Wang et al., 2006). In sour cherry, some expansin coding sequences have recently been identified (Karaaslan and Hrazdina, 2010). The objective of this study was to determine the expression levels of expansin genes to isolate a fruit ripening-specific promoter in order to design a specific plant transformation vector to increase shelf life of fruits. Using these sequences Balbontín et al. (2012) compared the transcript levels of two sweet cherry cultivars with differential susceptibility to cracking at different stages of fruit development. These studies suggest that the highest level of expansins transcripts was observed in the stage of color change of fruit in the susceptible cultivar, while the expression of this gene in the more resistant cultivar was greater and delayed, coinciding with the ripening of fruits. The latter could provide a greater capacity for cell wall extension to avoid development of cracks on fruit surface. Therefore, the analysis of expression patterns of this and other candidate genes can significantly help to elucidate the mechanisms underlying cherry fruit cracking.

\section{CONCLUSIONS}

The problem of rain-induced cracking in sweet cherries is a complex phenomenon with a large number of factors contributing to its development. Despite the different alternatives available through cultural management practices, cracking still represent a limiting factor for commercial production in areas where rain occurs during the harvest period, and planting tolerant cultivars is still the best option to reduce losses associated with this problem. Therefore, the search for new cultivars with greater resistance remains as a priority goal in breeding programs. The study of dynamics of fruit growth and analysis of composition of alkanes in cuticle can help us understand why some cultivars show a better performance against this phenomenon. Furthermore, sequencing of the genome and transcriptome of sweet cherry and the analysis of the structure and expression of genes such as expansins and $\beta$-galactosidase, both related to the physiological mechanisms inducing cracking, could be useful in early selection of genotypes with better tolerance in breeding programs.

\section{ACKNOWLEDGEMENTS}

Herman Silva is supported by CONICYT, FONDECYT/ Regular $\mathrm{N}^{\circ} 1120261$ and Innova CORFO (07CN13 PBT167); Juan Carlos Ríos is student of the PhD Biotechnology Program at Universidad Andrés Bello. Cristián Balbontín is supported by CONICYT, FONDECYT/Iniciación $\mathrm{N}^{\circ} 11100149$; Héctor Ayala is student of Bio Engineering at Universidad de Concepción.

\section{LITERATURE CITED}

Alkio, M., U. Jonas, T. Sprink, S. van Nocker, and M. Knoche. 2012. Identification of putative candidate genes involved in cuticle formation in Prunus avium (sweet cherry) fruit. Annals of Botany 110:101-112.

Argout, X., J. Salse, J.M. Aury, M.J. Guiltinan, G. Droc, J. Gouzy, et al. 2011. The genome of Theobroma cacao. Nature Genetics 43:101-108.

Balbontín, C., H. Ayala, J. Carrasco, and D. Avilés. 2012. Transcriptional analysis of genes involved in cherry fruit cracking. VII Reunión Anual de Biología Vegetal, Pucón, Chile. Abstract in press. 
Bastías, R.M., R. Wilckens, A. Venegas, y A. Muñoz. 2010. Dinámica de crecimiento de fruto en cultivares de cerezo (Prunus avium L.) con alta, moderada y baja susceptibilidad a partidura. Agro-Ciencia 26:81-89.

Bergamini, A., e G. Tomasi. 1994. Ciliegio in coltura protetta. L'Informatore Agrario 46:63-66.

Boese, R., H.C. Weiss, and D. Bláser. 1999. The melting point alternation in the short-chain n-alkanes: Single-crystal X-ray analyses of propane at $30 \mathrm{~K}$ and of n-butane to n-nonane at $90 \mathrm{~K}$. Angewandte Chemie International Edition 38:988-992.

Brummell, D.A., and M.H. Harpster. 2001. Cell wall metabolism in fruit softening and quality and its manipulation in transgenic plants. Plant Molecular Biology 47:311-339.

Brummell, D.A., M.H. Harpster, P.M. Civello, J.M. Palys, A.B. Bennett, and P. Dunsmuir. 1999. Modification of expansin protein abundance in tomato fruit alters softening and cell wall polymer metabolism during ripening. The Plant Cell 11:2203-2216.

Buda, G.J., T. Isaacson, A.J. Matas, D.J. Paolillo, and J.K. Rose. 2009. Three-dimensional imaging of plant cuticle architecture using confocal scanning laser microscopy. The Plant Journal 60:378-385.

Christensen, J.V. 1972. Cracking in cherries. III. Determination of cracking susceptibility. Acta Agriculturae Scandinavica 22:128-136.

Christensen, J.V. 1973. Cracking susceptibility in relation to the growth rhythm of the fruit. Craking in cherries VI. Acta Agriculturae Scandinavica 23:52-54.

Christensen, J.V. 1975. Cracking susceptibility in relation to fruit size and firmness. Cracking in cherries VII. Acta Agriculturae Scandinavica 25:11-13

Christensen, J.V. 1976. Cracking in cherries. Danish Journal of Plant and Soil Science 80:289-324.

Christensen, J.V. 1996. Rain-induced cracking of sweet cherries: Its causes and prevention. p. 297-327. In Webster, A.D., and N.E. Looney (eds.) Cherries: Crop physiology, production and uses. CAB International, London, UK.

Christensen, J.V. 2000. Performance in Denmark of 16 European varieties of sweet cherry. Journal of American Pomological Society 54:172-176.

Considine, J.A., and P.E. Kriedemann. 1972. Fruit splitting in grapes. Determination of the critical turgor pressure. Australian Journal of Agricultural Research 23:17-23.

Coombe, B.G. 1976.The development of fleshy fruits Annual Review of Plant Physiology 27:507-528.

Cosgrove, D.J. 2000. Loosening of plant cell walls by expansins. Nature 407:321-326.

Croteau, R., T.M. Kutchan, and N.G. Lewis. 2000. Natural products secondary metabolites. p. 1250-1318. In Buchanan, B., W. Gruissem, and R. Jones (eds.) Biochemistry and molecular biology of plants. American Society of Plant Physiologists, Rockville, Maryland, USA.

Dirlewanger, E., E. Graziano, T. Joobeur, F. Garriga-Calderé, P. Cosson, W. Howad, and P. Arús. 2004. Comparative mapping and marker-assisted selection in Rosaceae fruit crops. Proceedings of the National Academy of Sciences of the United States of America 101:9891-9896.

Ellena, M., A. Aguilera, S. Ferrada, A. Montenegro, J. Guerrero, y A. Rombolá. 2006. Cultivo del cerezo para la zona sur de Chile. Boletín INIA No 135 . p. 136-153.

Facteau, T.J., K.E. Rowe, and N.E. Chestnut. 1987. Response of 'Bing' and 'Lambert' sweet cherry fruit to preharvest calcium chloride applications. HortScience 22:271-273.

Fernandez, R.T., and J.A. Flore. 1998. Intermittent application of $\mathrm{CaCl}_{2}$ to control cracking of sweet cherry. Acta Horticulturae 468:683-689.

Gibert, C., F. Lescorruet, M. Génard, G. Vercambre, and A. Pérez. 2005. Modelling the effect of fruit growth on surface conductance to water vapour diffusion. Annals of Botany 95:673-683.

Glenn, G.M., and B.W. Poovaiah. 1989. Cuticular properties and postharvest calcium application influence cracking of sweet cherries. Journal of the American Society for Horticultural Science 114:781-788

Heacox, L. 2001. Curb cherry cracking. Fruit Grower 121(4):16.

Karaaslan, M., and G. Hrazdina. 2010. Characterization of an expansin gene and its ripening-specific promoter fragments from sour cherry (Prunus cerasus L.) cultivars. Acta Physiologiae Plantarum 32:1073-1084.

Kasai, S., H. Hayama, Y. Kashimura, S. Kudo, and Y. Osanai. 2008. Relationship between fruit cracking and expression of the expansin gene MdEXPA3 in 'Fuji' apples (Malus domestica Borkh.) Scientia Horticulturae 116:194-198.

Kertesz, Z.I., and B.R. Nebel. 1935. Observations on the cracking of cherries. Plant Physiology 10:763-772.

Klagges, C., J.A Campoy, J. Quero-García, A. Guzmán, L. Mansur, E. Gratacós, et al. 2013. Construction and comparative analyses of highly dense linkage maps of two sweet cherry intra-specific progenies of commercial cultivars. Plos One 8(1):e54743. doi:10.1371/journal.pone.0054743.

Knoche, M., S. Peschel, M. Hinz, and M. Bukovac. 2000. Studies on water transport through the sweet cherry fruit surface: characterizing conductance of the cuticular membrane using pericarp segments. Planta 212:127-135.

Knoche, M., S. Peschel, M. Hinz, and M. Bukovac. 2001. Studies on water transport through the sweet cherry fruit surface: Conductance of the cuticle in relation to fruit development. Planta 213:927-936.

Koepke, T., S. Schaeffer, C. Hendrickson, D. Jiwan, C. Duncan, V. Krishnan, et al. 2010. Sweet cherry genomics: Cherry genome sequencing facilitates investigations into fruitlet abscission and rootstock-scion interactions controlling floral bud number. Plant and Animal Genome XVIII Conference, San Diego, USA. January 9-13. Scherago International, Jersey City, New Jersey, USA.

Kovács, E., Z. Kristóf, R. Perlaki, and D. Szőllősi. (2008). Cell wall metabolism during ripening and storage of nonclimacteric sour cherry (Prunus cerasus L., cv. Kántorjánosi). Acta Alimentaria 37:415-426.

Kunst, L., and A.L. Samuels. 2009. Plant cuticles shine: advances in wax biosynthesis and export. Current Opinion in Plant Biology 12:721-727

Lane, W., M. Meheriuk, and D. MacKenzie. 2000. Fruit cracking of a susceptible, an intermediate, and a resistant sweet cherry cultivar. HortScience 35:239-242.

Lang, G., and J. Flore. 1999. Reducing rain cracking in cherries. Good Fruit Grower 50(4):34-38.

Lang, G., J. Flore, S. Southwick, A. Azarenko, T. Facteau, and F. Kappel. 1997. Overtree sprinkler calcium shows widespread potential to reduce cherry rain-cracking. Good Fruit Grower 48:27-30.

Lang, G., and D. Hayden. 1997. Overhead sprinkler calcium application can reduce rain-cracking. Proceedings Washington State Horticultural Association 92:283-288

Leide, J., U. Hildebrandt, K. Reussing, M. Riederer, and G. Vogg. 2007. The developmental pattern of tomato fruit wax accumulation and its impact on wall disassembly. The Plant Cell Wall 8:264-324.

Lugli, S., S. Sansavini, e W. Monari. 2001. Prevenzione dele spaccature dei frutti di ciliegio con coperture plastiche. Frutticoltura 3:24-31.

Ma, J.F. 2007. Effecti benefici e sistemi d’assorbimento del silicio nelle piante. Italus Hortus 14:1-13.

McQueen-Mason, S.J., and D.J. Cosgrove. 1995. Expansin mode of action on cell walls. Analysis of wall hydrolysis, stress relaxation, and biding. Plant Physiology 107:87-100.

McQueen-Mason, S., D.M. Durachko, and D.J. Cosgrove. 1992. Two endogenous proteins that induce cell wall extension in plants. The Plant Cell 4:1425-1433.

Measham, P.F., A. Bound, J. Gracie, and S.J. Wilson. 2009. Incidence and type of cracking in sweet cherry (Prunus avium L.) are affected by genotype and season. Crop \& Pasture Science 60:1002-1008 
Measham, P.F., A.J. Gracie, S.J. Wilson, and S.A. Bound. 2010. Vascular flow of water induces side cracking in sweet cherry (Prunus avium L.) Advances in Horticultural Science 24:243-248.

Mintz-Oron, S., T. Mandel, I. Rogachev, L. Feldberg, O. Lotan, M. Yativ, et al. 2008. Gene expression and metabolism in tomato fruit surface tissues. Plant Physiology 147:823-851.

Moctezuma, E., D.L. Smith, and K.C. Gross. 2003. Antisense suppression of a beta-galactosidase gene (TBG6) in tomato increases fruit cracking. Journal of Experimental Botany 54:20252033.

Moing, A., C.H. Renaud, H. Christmann, L. Foulihaux, Y. Tauzin, A. Zanetto, et al. 2004. Is there a relation between changes in osmolarity of cherry fruit flesh or skin and fruit cracking susceptibility? Journal of the American Society for Horticultural Science 129:635-641.

Palma, F. 2009. Efecto de la aplicación de cera y cloruro de calcio sobre el control de partidura y calidad en cerezas Van y Kordia. 30 p. Tesis Ingeniero Agrónomo. Universidad de Concepción, Facultad de Agronomía, Chillán, Chile.

Peschel, S., R. Franke, L. Schreiber, and M. Knoche. 2007. Composition of cuticle of developing sweet cherry fruit. Phytochemistry 68:1017-1025.

Podestá, L., M. Rodríguez, F. Gil, y C. Arjona. 2001. Efecto del ácido giberélico y del calcio sobre el tamaño, agretamiento y otros parámetros de calidad en frutos de cerezo (Prunus avium L.) cv. Bing. Investigación Agraria Producción y Protección Vegetales 16:37-48

Quero-Garcia, J., J.A. Campoy, J. Joly, Y. Tauzin, U. Rosyara, A. Iezzoni, and E. Dirlewanger. 2012. QTL detection for fruit weight, fruit firmness, and fruit cracking tolerance in sweet cherry. International Plant \& Animal Genome XX Conference, San Diego, California, USA. 14-18 January. Scherago International, Jersey City, New Jersey, USA.

Quero-Garcia, J., A. Fodor, A. Reignier, G. Capdeville, J. Joly, Y. Tauzin, et al. 2009. QTL detection of important agronomic traits for sweet cherry breeding. ISHS $6^{\text {th }}$ International Cherry Symposium, Reñaca, Viña del Mar. 15-19 November. International Society for Horticultural Science, Leuven, Belgium.

Rios, J.C., J. Maldonado, E. Lang, and H. Silva. 2011. Molecular and bioinformatics analysis of factors involved in the cracking susceptibility in different varieties of cherry. Plant and Animal Genome XIX Conference, San Diego, California, USA. 15-19 January. Scherago International, Jersey City, New Jersey, USA.

Roser, I. 1996. Investigations on cracking susceptibility of sweet cherry cultivars. Acta Horticulturae 410:331-337.

Samuels, L., L. Kunst, and R. Jetter. 2008. Sealing plant surfaces: Cuticular wax formation by epidermal cells. Annual Review of Plant Biology 59:683-707.

Sawada, E. 1931. Studies on the cracking of cherries. Agriculture and Horticulture 6:864-892.

Schrader, L., and J. Sun. 2005. Cherry cracking: Causes and suppression. Proceedings of the Oregon Horticultural Society. 5 p.

Sekse, L. 1995. Fruit cracking in sweet cherries (Prunus avium L.) Some physiological aspects - A mini review. Scientia Horticulturae 63:135-141.

Sekse, L. 1998. Fruit cracking mechanism in sweet cherries (Prunus avium L.) - A review. Acta Horticulturae 468:637-648.

Shulaev, V., D.J. Sargent, R.N. Crowhurst, T.C. Mockler, O. Folkerts, A.L. Delcher, et al. 2011. The genome of woodland strawberry (Fragaria vesca). Nature Genetics 43:109-116.

Silva, H., J.C. Rios, J. Maldonado, H. Duchens, E. Lang, and B. Carrasco. 2012. A functional genomics approach to understand cracking susceptibility in sweet cherries (Prunus avium). Sixth
Rosaceous Genomics Conference, San Michele all'Adige, Trento, Italy. 30 September-4 October. Edmund Mach Foundation, Trento, Italy.

Simon, G. 2006. Review on rain induced fruit cracking of sweet cherries (Prunus avium L.), its causes and the possibilities of prevention. International Journal of Horticultural Science 12:2735

Smith, D.L., J.A. Abbott, and K.C. Gross. 2002. Down-regulation of tomato B-galactosidase 4 results in decreased fruit softening. Plant Physiology 129:1755-1762.

Sorrenti, G., M. Quartieri, S. Caruso, S. Lugli, e A. Rombol. 2008 Efficace l'impiego di silicato di sodio e cloruro di calico per ridurre lo spacco dei frutti. Frutticoltura 70:28-32.

Torres, C.A., A. Yuri, R. Bastías, A. Venegas, and A. Neira. 2009b. Determination of sweet cherry (Prunus avium L.) susceptibility to rain-cracking using the "immersion" method. 15-19 p. VI International Cherry Symposium, Reñaca, Chile. 15-19 November International Society for Horticultural Sciences (ISHS) and Facultad de Agronomía e Ingeniería Forestal, Departamento de Fruticultura y Enología, Pontificia Universidad Católica de Chile (PUC), Viña del Mar, Chile.

Torres, C.A., J.A. Yuri, A. Venegas, and V. Lepe. 2009a. Use of a lipophilic coating pre-harvest to reduce sweet cherry (Prunus avium L.) rain-cracking. 15-19 p. VI International Cherry Symposium, Reñaca, Chile. 15-19 November. International Society for Horticultural Sciences (ISHS) and Facultad de Agronomía e Ingeniería Forestal, Departamento de Fruticultura y Enología, Pontificia Universidad Católica de Chile (PUC), Viña del Mar, Chile.

Tucker, R. 1934. A varietal study of the susceptibility of sweet cherries to cracking. University of Idaho Agriculture Experimental Station Bulletin 211:1-15.

Valenzuela, L. 2007. Partidura en cerezas: causas y prevención. Revista Frutícola 28:54-64.

Velasco, R., A. Zharkikh, J. Affourtit, A. Dhingra, A. Cestaro, A. Kalyanaraman, P. Fontana, et al. 2010. The genome of the domesticated apple (Malus $\times$ domestica Borkh.) Nature Genetics 42:833-839.

Verner, L., and E.C. Blodgett. 1931. Physiological studies of the cracking of sweet cherries. University of Idaho Agriculture Experimental Station Bulletin $\mathrm{N}^{\circ} 184.15 \mathrm{p}$.

Vogg, G., S. Fischer, J. Leide, E. Eyal, R. Jetter, A. Levy, and M. Riederer. 2004. Tomato fruit cuticular waxes and their effects on transpiration barrier properties: functional characterization of a mutant deficient in a very-long-chain fatty acid beta-ketoacylCoA synthase. Journal of Experimental Botany 55:1401-1410.

Wakasa, Y., Y. Hatsuyama, A. Takahashi, T. Sato, M. Niizeki, and T. Harada. 2003. Divergent expression of six expansin genes during apple fruit ontogeny. European Journal of Horticultural Science 68:253-259.

Wang, Y., W. Lu, J. Li, and Y. Jiang. 2006. Differential expression of two expansin genes in developing fruit of cracking-susceptible and -resistant litchi cultivars. Journal of the American Society for Horticultural Science 131:118-121.

Yamamoto, T., M. Kudo, and S. Watanabe. 1990. Fruit cracking and characteristics of fruit thickening in "Satonishiki"cherry. Journal Japanese Society for Horticultural Science 59:325-332.

Yamamoto, T., H. Satoh, and S. Watanabe. 1992. The effects of calcium and naphtalene acetic acid sprays on cracking index and natural rain cracking in sweet cherry fruits. Journal of the Japanese Society for Horticultural Sciences 61:507-511.

Zielinski, B.Q. 1964. Resistance of sweet cherry varieties to fruit cracking in relation to fruit and pit size and fruit color. Proceedings of the American Society for Horticultural Science 84:98-102. 